COMMENTARY ON COVID-19 AND THE FoOd SYSTEM

\title{
Immediate impacts of COVID-19 measures on bean production, distribution, and food security in eastern Africa
}

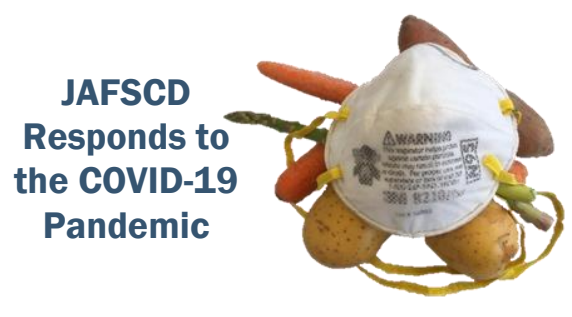

\author{
Eileen Nchanji a * \\ International Center for Tropical Agriculture \\ Cosmas Kweyu Lutomia ${ }^{b}$ and David Karanja ${ }^{c}$ \\ Kenya Agricultural and Livestock Research
}

\begin{abstract}
Submitted October 3, 2020 / Published online January 22, 2021
Citation: Nchanji, E., Lutomia, C. K., \& Karanja, D. (2021). Immediate impacts of COVID-19 measures on bean production, distribution, and food security in eastern Africa. Journal of Agriculture, Food Systems, and Community Development, 10(2), 259-263. https://doi.org/10.5304/jafscd.2021.102.007
\end{abstract}

Copyright (C) 2021 by the Authors. Published by the Lyson Center for Civic Agriculture and Food Systems. Open access under CC-BY license.

\begin{abstract}
The outbreak of coronavirus was expected to adversely affect African countries more than any other region in the world. This assertion was based on the existing conditions in sub-Saharan Africa that exposed the region to the dire consequences of the pandemic. Previously existing underlying conditions that affected the food system include a high dependence on trade for inputs supply, the adverse effects of climate change, crop pests and diseases, poverty, low input use, weak institutions and ineffective policies, and insecurity and conflicts. We collected data from farmers, aggregators, bean research coordinators, and urban and peri-urban consumers in five Eastern African countries in order to describe the immediate impacts of the pandemic on the bean value chain. Access to seed and labor appear to be the

a * Corresponding author: Eileen Nchanji, Gender Specialist, International Center for Tropical Agriculture; c/o ICIPE-International Centre of Insect Physiology and Ecology; Duduville Campus Off Kasarani Road; P.O. Box 823-00621; Nairobi, Kenya; e.nchanji@,cgiar.org

b Cosmas Kweyu Lutomia, Research Fellow, Kenya Agricultural and Livestock Research, Nairobi, Kenya; mascos05@gmail.com

c David Karanja, Breeder, Kenya Agricultural and Livestock Research, Nairobi, Kenya; karanjadr@yahoo.com
\end{abstract}

\section{Acknowledgments}

We acknowledge technical support from the Pan-African Beans Research Alliance (PABRA) through the Alliance of Bioversity International and the International Center for Tropical Agriculture (CIAT), and financial support from Global Affairs Canada and the Swiss Agency for Development and Cooperation (SDC). Many thanks go to the farmers and other stakeholders who provided information without which this study would not have been successful. 
most critical impacts of the pandemic on bean production. There are observable differences in patterns and frequency of bean consumption in these regions, suggesting that the effect of the pandemic depends on the level of implementation of containment measures and pre-COVID-19 underlying conditions that affect the food systems. In the mid to long-term, the pandemic may disrupt food systems, resulting in hunger, malnutrition, and food insecurity. Thus, governments should support farmers and businesses in becoming resilient to exogenous shocks through increased efficiency in supply chains, capacity building, and the adoption of modern digital technology.

\section{Keywords}

Food System, COVID-19, Pandemic, Common Bean, Labor, Inputs, Value Chain, Eastern Africa

\section{Introduction}

Common bean is the most grown and consumed legume in Africa, especially in Eastern African countries (Figure 1). Beans, as a source of cheap protein and micronutrients (iron and zinc), have been earmarked as vital to improving and safeguarding rural incomes, food security, and nutrition (Nassary, Baijukya \& Ndakidemi, 2020). However, beans are mostly grown by smallholder farmers, who are disproportionately affected by the adverse effects of climate change (Pais, Jayaram, \& van Wamelen, 2020; Pratt, 2015). Most smallholder farmers in the region are low consumers of agricultural technology such as certified seed and fertilizer, relying mostly on saved seeds. Furthermore, the region relies on trade for the supply of farm inputs. Thus, the implementation of coronavirus containment measures and cross-border restrictions threatens to slow down beans' contribution to the achievement of the United Nations Sustainable Development Goals number 1 and 2 (Nchanji et al., 2020).

This commentary is based on survey data collected from six countries in the eastern African bean corridor per the Pan African Bean Research Alliance (PABRA) classification: Kenya, Uganda, Tanzania, Burundi, and the Democratic Republic of Congo (DRC). Governments have been implementing multiple public health policies with varying degrees of strictness since March, when the region first started reporting cases of the coronavirus. Kenya and Uganda, guided by their respective constitutions and public health policies, responded expeditiously. For instance, Kenya imposed absolute restrictions on movement from four highrisk counties, a partial lockdown by declaring a duskto-dawn curfew, and closed its borders to only allow essential movements. The Ugandan government declared a lockdown in March, banned transport within the country, closed its borders, and imposed stay-at-home orders. In

\section{Figure 1. Diverse Common Bean Grown by Smallholder Women Farmers in Uganda, Africa}

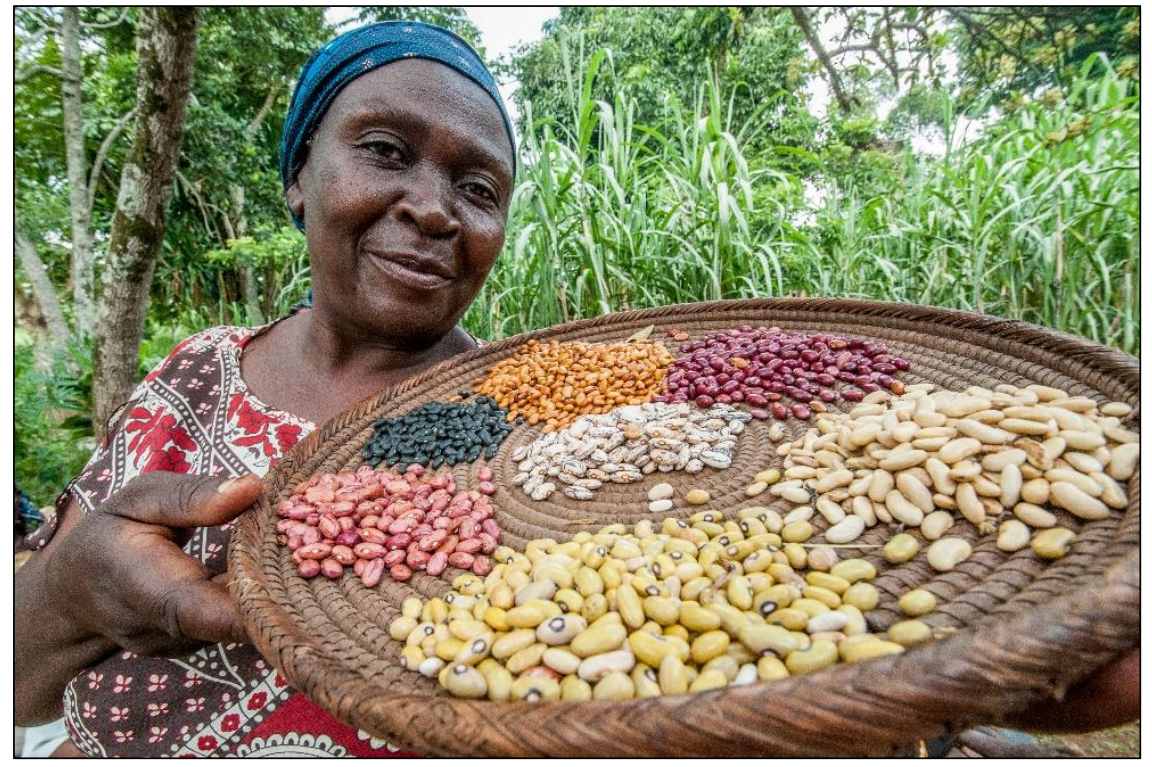

Photo by 2016CIAT/Georgina Smith. 
contrast, Tanzania and Burundi were more relaxed in their actions to combat the spread of the virus. The Tanzanian government prioritized its economy and relied on "divine protection." At one point, the Burundian government deported World Health Organization officials for criticizing its laxity in implementing reasonable measures to contain the spread of the virus.

\section{COVID-19's Impacts on Bean Production}

Nearly one-third of farmers we surveyed in the region reported that the pandemic had disrupted their access to seed and caused a rise in the prices of inputs and labor. Farmers' responses are further supported by bean aggregators, who mentioned that they faced challenges in distributing seed to contracted farmers. Bean program research coordinators in different countries projected that the pandemic would reduce the production of certified seed due to difficulties in mobilizing labor for seed production. The preliminary findings confirm concerns that the pandemic would disrupt the input supply system (Rubyogo, Nchanji, Mabeya, Onyango, \& Ngombalu, 2020).

The levels of strictness in the application of coronavirus containment measures differed by country, suggesting possible differences in the impact of COVID-19 on bean production. Whereas more farmers in Uganda and the DRC reported that bean production was impacted by COVID-19, those in Tanzania and Burundi were least affected by the pandemic (Table 1). The results appear to confirm Burundian and Tanzanian governments' skepticism about COVID-19, with Tanzania declaring that it was coronavirusfree in under two months after it recorded its first case. The seed unavailability problem was dire in the DRC compared to other countries in the bean corridor. On the other hand, the high price of labor was identified by Tanzanian farmers as the main challenge. While drastic and strict measures in Kenya resulted in high costs of labor and inputs, they caused fertilizer unavailability and low bean grain prices and demand in Uganda.

\section{Impact on Bean Distribution and Trade}

The impact of containment measures is transmitted directly to businesses involved in downstream bean value chain activities. First, aggregators in Kenya, Tanzania, and Uganda indicated that the pandemic affected the volumes of grain they transacted because of the closure of informal markets and schools. The pandemic has compelled aggregators to scale down business operations due to high logistic, transport, and storage costs. Before COVID-19, bean trade volume had increased to 18,000 metric tons $(19,842$ short tons), which was 18\% higher than the first quarters' average in five years (Market Analysis

\section{Table 1. CoVID-19 Effects Disaggregated by Country, Eastern Africa}

\begin{tabular}{lcccc}
\hline COVID-19 effects & Kenya & DRC & Tanzania & Uganda \\
\hline High prices for hired labor & 22.22 & 1.22 & 63.64 & \\
\hline Higher prices for inputs & 22.22 & 19.51 & & \\
\hline Low demand in the market & 22.22 & & 9.09 & 21.43 \\
\hline Fertilizer unavailability & 11.11 & 1.22 & & 14.29 \\
\hline Low price in the market & 11.11 & 6.1 & 9.09 & 28.57 \\
\hline Difficulties in transporting the harvest to the point of sale & 11.11 & & 9.09 & 14.29 \\
\hline Seed unavailability & & 47.56 & & \\
\hline Delay in planting & & 15.85 & & \\
\hline Delayed harvest & & & & \\
\hline Difficulty in accessing agronomic information & & & & \\
\hline
\end{tabular}


Subgroup, 2020). Thus, according to aggregators, processors, and coordinators, the pandemic has harmed bean trade volumes in the region.

\section{Impact on Food Security}

In Eastern Africa, common bean is grown mostly for household consumption, with the surplus sold to the market. Here we provide a brief overview of the descriptive results of the possible effects of COVID-19 on food consumption in rural and urban areas during the COVID-19 pandemic. Nearly half $(49 \%)$ of the farmers did not change bean consumption patterns during COVID-19, while the rest changed. While less than a fifth of them ate less bean, one-third ate more bean during COVID-19 (Figure 2). Turning to peri-urban and urban consumers, more than half $(56 \%)$ indicated that their bean consumption patterns had not changed, a fifth (21\%) and nearly one-quarter $(23 \%)$ reported they consumed less bean and more bean during the pandemic, respectively.

The results show that the frequency of bean consumption was reduced in urban and peri-urban areas during COVID-19, with Uganda, Burundi, and the DRC being most affected (Table 2). This could be attributed to transportation challenges experienced during the pandemic. In contrast, bean consumption frequency in Tanzania increased during the pandemic, possibly due to less strict containment measures. Most urban consumers rely on the informal market for bean grain supply. Therefore, the market closure

Figure 2. Changes in Food Consumption Patterns in Rural, Urban, and Peri-urban Areas of Eastern Africa During the COVID-19 Pandemic, 2020

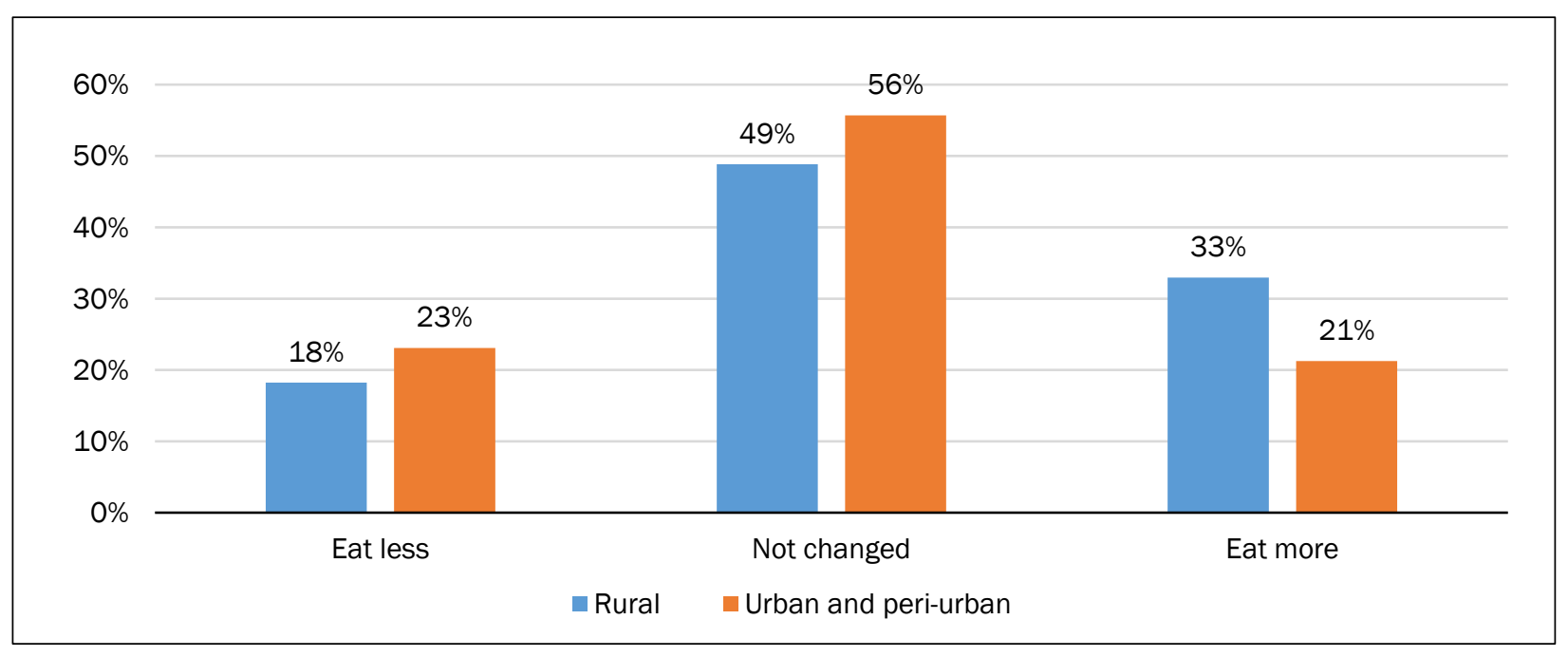

Table 2. Proportions of Consumers' Frequency of Bean Consumption a Week Before COVID-19 (in February 2020) and During COVID-19 (in July 2020) by Country, Eastern Africa

\begin{tabular}{lrrllr}
\hline & \multicolumn{5}{c}{ Before CovID-19 } \\
\cline { 2 - 6 } & Everyday & $>$ Thrice & Thrice & Twice & Once \\
\hline Burundi & 67.57 & 8.11 & 10.81 & 13.51 & \\
\hline Kenya & 2.86 & 14.29 & 25.71 & 34.29 & 22.86 \\
\hline DRC & 31.11 & 17.78 & 31.11 & 15.56 & 4.44 \\
\hline Tanzania & 5.36 & 46.43 & 16.07 & 25.00 & 7.14 \\
\hline Uganda & 2.27 & 6.82 & 11.36 & 20.45 & 59.09 \\
\hline
\end{tabular}

\begin{tabular}{crllr}
\multicolumn{5}{c}{ During COVID-19 } \\
\hline Everyday & $>$ Thrice & Thrice & Twice & Once \\
\hline 40.54 & 10.81 & 24.32 & 24.32 & \\
\hline 2.86 & 5.71 & 20.00 & 40.00 & 31.43 \\
\hline 20 & 15.56 & 20 & 24.44 & 20.00 \\
\hline 6.25 & 53.57 & 13.39 & 19.64 & 7.14 \\
\hline 27.27 & 15.91 & 15.91 & 22.73 & 18.18 \\
\hline
\end{tabular}


and restricted movement from production hubs limited consumers' access to and availability of beans in urban areas.

\section{Conclusion and Policy Implications}

Preliminary results show that COVID-19 measures have had an unprecedented impact on bean value chains across Eastern African countries. The pandemic has affected bean production by limiting farmers' access to seed and fertilizer and creating low grain prices and low demand. The pandemic has also affected the distribution of seed and grain by aggregators, affecting their business models and forcing them to scale down business operations. The containment measures have impeded cross-border trade. For these reasons, the pandemic is a threat to achieving the global goals of reducing hunger, malnutrition, and poverty. In the meantime, Eastern African countries need to address the immediate and short-term impacts of the pandemic by:

- Strengthening existing farmer support programs to improve access to and availability of seed and other inputs;

- Supporting businesses in developing new and resilient business models with an emphasis given to digitizing business operations and capacity building; and

- Classifying agriculture as an essential sector and agricultural workers as essential service providers.

\section{References}

Market Analysis Subgroup. (2020). East Africa crossborder trade bulletin. Retrieved from https://ratin.net/assets/uploads/files/997ee-quarterly-gha-cross-border-trade-bulletin-april-2020.pdf

Nassary, E. K., Baijukya, F., \& Ndakidemi, P. A. (2020). Intensification of common bean and maize production through rotations to improve food security for smallholder farmers. Journal of Agriculture and Food Research, 2, 100040. https://doi.org/10.1016/j.jafr.2020.100040

Nchanji, E., Lutomia, C. K., Chirwa, R., Templer, N., Rubyogo, J. C., \& Onyango, P. (2020). Immediate impacts of COVID-19 pandemic on bean value chain in selected countries in sub-Saharan Africa. Agricultural Systems, 103034. https://doi.org/10.1016/j.agsy.2020.103034

Pais, G., Jayaram, K., \& van Wamelen, A. (2020, June 5). Safeguarding Africa's food systems through and beyond the crisis. McKinsey \& Company. Retrieved from https://www.mckinsey.com/featured-insights/middle-east-andafrica/safeguarding-africas-food-systems-through-and-beyond-the-crisis

Pratt, A. N. (2015). The challenge of increasing agricultural productivity in Africa south of the Sahara [Blot post]. International Food Policy Research Institute (IFPRI). Retrieved from https://www.ifpri.org/blog/challenge-increasing-agricultural-productivity-africa-south-sahara

Rubyogo, J. C., Nchanji, E., Mabeya, J., Onyango, P., \& Ngombalu, J. (2020, September 4). Covid-19 hits East African agri value chains. African Business. Retrieved from https://africanbusinessmagazine.com/sectors/agriculture/covid-19-hits-east-african-agri-value-chains/ 